Nadzieja Bąkowska

Wydział Języków, Literatur i Kultur Współczesnych, Uniwersytet Boloński

\title{
Maska czy gęba? Operetka Witolda Gombrowicza w kontekście komedii dell'arte
}

1. „Niechże to będzie maskarada!” - między operetką, komedią dell'arte a groteską i absurdem

Operetka (1966) Witolda Gombrowicza [1997: 260] jest parodystyczną i groteskową stylizacją na tytułową formę teatru muzycznego. Autor od początku sygnalizuje, że będzie „majstrował przy operetkowym idiomie" [Jarzębski 2007: 91]:

[...] operetka w swym boskim idiotyzmie, w niebiańskiej sklerozie, we wspaniałym uskrzydlaniu się swoim za sprawą śpiewu, tańca, gestu, maski², jest dla mnie teatrem doskonałym, doskonale teatralnym. [...] Ale... jak tu nadziać marionetkową pustotę operetkową istotnym dramatem? [Gombrowicz 1997: 257]

W utworze rozpoznawalne są elementy nawiązujące do schematu operetkowego ${ }^{3}$ : przeplatanie partii wokalnych z niemuzycz-

1 Gombrowicz 1997: 260.

2 Notabene: maska nie jest stałym ani koniecznym elementem operetki. [Chomicki 2001: 635-636].

3 Na temat związków Gombrowiczowskiej Operetki z gatunkiem operetki pisali Tadeusz Nyczek [1996: 49-70] i Tamara Trojanowska [1989: 168-174]. 
nymi dialogami i monologami, akompaniament muzyczny, lekki temat, akcja zbudowana wokół perypetii sercowych bohaterów, komediowy charakter. W dramacie Gombrowicza w miarę rozwoju wydarzeń elementy te potwornieją i ulegają groteskowej deformacji aż po absurdalizację świata przedstawionego i wywrócenie do góry nogami schematów będących przedmiotem stylizacji. W utworze manifestują się jednak też cechy, które trudno byłoby zaliczyć do stałych wyróżników gatunkowych operetki, a ich rodowód należałoby raczej łączyć z paradygmatem komedii dell'arte. Do takich cech należą: doniosła rola maski, typowe postaci, wywodzące się $\mathrm{z}$ różnych grup społecznych, ukształtowanie języka postaci ujawniające ich pochodzenie, karykatura (u Gombrowicza realizuje się m.in. w sposobie przedstawienia grup społecznych, a w komedii dell'arte również w sposobie przedstawienia mieszkańców różnych regionów Włoch), improwizacja, a także niektóre elementy strukturalne, takie jak l'argomento, czyli streszczenie zawartości utworu, które poprzedza tekst właściwy dramatu ${ }^{4}$.

W analizowanym utworze konwencja operetki, konwencja komedii dell'arte i konwencje w ogóle stanowią skorupy-maski władające człowiekiem i sztukąs. W groteskowo-parodystycznym wykoślawieniu te elementy Operetki, które wykazują powinowactwa z komedią dell'arte, w szczególny sposób stają się narzędziem zerwania maski, demaskacji formy i destrukcji teatralności, przy czym paralelizmy te mają charakter raczej powierzchowny. Komedia dell'arte jest ewokowana jako gatunek, który odznacza się wyjątkową teatralnością oraz którego kategorie „maski” i „konwencji” są niemalże synonimami. W artykule komedia dell'arte rozpatrywana jest jedynie jako konwencja, a analiza jej związków z dramatem Gombrowicza opiera się na odniesieniach do jej zasadniczych wyznaczników gatunkowych, nie uwzględnia natomiast odwołań do konkretnych utworów. W zakresie cech komedii dell'arte scenki niezwiązane z zasadniczą akcją utworu.

5 Na temat Gombrowiczowskiej koncepcji „gęby” i formy pisał Jerzy Jarzębski [1971: 69-96]; odnośnie do stosunku autora Ferdydurke wobec konwencji literackich i artystycznych zob. np. pracę Michała Głowińskiego [2002]. 
główny punkt odniesienia stanowi opracowanie Konstantego Miklaszewskiego [1981 $]^{6}$.

\section{Operetka a komedia dell'arte}

Jednym z istotniejszych paralelizmów między utworem Gombrowicza a komedią dell’arte jest obecność na scenie postaci-masek. Są to postaci nie tyle bliźniacze, ile raczej analogiczne w swej szablonowości i reprezentatywności. Już na początku pierwszego aktu Operetki, jeszcze bez udziału dosłownie rozumianych masek (te bowiem pojawiają się dopiero w II akcie podczas balu maskowego), lecz przy pomocy garderoby, akcesoriów, sposobu poruszania i wysławiania ${ }^{7}$, zostają wyłonione postaci-typy, reprezentanci różnych warstw społecznych:

Na pierwszym planie z boku GRUPA PAŃSKA: BANKIER, GENERAE, PROFESOR, MARKIZA. Stroje sprzed 1914 roku, obfite: mundur, tużurki, szapoklaki, bokobrody, kołnierzyki, laski, galony, etc. Dystyngowane maniery: ukłony, uśmiechy, grzeczności etc. W głębi z lewej strony GRUPA LOKAJSKA: czterech, w liberii, gęby lokajskie. Zza kościoła wychodzi hrabia SZARM HIMALAJ, złoty młodzieniec, lat 35, birbant i lampart blasé: frak, szapoklak, rękawiczki, laseczka, monokl. Za nim jego lokaj Władysław. [Gombrowicz 1997: 264]

Przygotowując niniejszy szkic, korzystałam z włoskiego przekładu książki Konstantego Miklaszewskiego. Z jednej strony było to związane z pobytem badawczym w Bolonii (i dostępem w tym czasie głównie do włoskojęzycznej literatury przedmiotu), z którym zbiegła się praca nad artykułem, z drugiej z pragnieniem pozostania w duchu konwencji komedii dell'arte, zrodzonej na gruncie kultury włoskiej i z nią najgłębiej związanej. Należy jednak odnotować, że opracowanie to jest dostępne również w polskim tłumaczeniu Sławy i Michała Browińskich, które ukazało się nakładem Zakładu Narodowego im. Ossolińskich w 1961 roku. Na temat cech i historii gatunku komedii dell'arte ukazały się także liczne prace [por. Pandolfi 1957-1961; Nicoll 1967; Taviani 1969; Mariti, red. 1980; Apollonio 1982; Fava 1999; Surma-Gawłowska 2015].

7 Podobnie jak w komedii dell’arte również w Operetce kategorię maski można rozszerzyć o szeroko rozumiany kostium, charakteryzację, rekwizyty, jakimi dysponują postaci. 
U Gombrowicza każda postać nie tylko stanowi kwintesencję grupy społecznej, do której należy (można wręcz mówić o przesyceniu ${ }^{8}$ cechami typowymi) i ukazana jest w krzywym zwierciadle, lecz także sprawia wrażenie pustej skorupy, nieodznaczającej się żadnymi cechami poza tymi typowymi. Są to postaci-marionetki, odgrywające role narzucone im przez rozmaite konwencje, zarówno literackie, jak i społeczne. Postaci wydają się nieautentyczne, przybierają sztuczne i groteskowe pozy (z didaskaliów dowiadujemy się np., że postać „zastyga w dystyngowanej pozie” [Gombrowicz 1997: 264], „przechadza się [...] impertynencko” [Gombrowicz 1997: 267], bohaterowie „defilują jeden przed drugim elegancko” [Gombrowicz 1997: 291]), wykonują teatralne gesty (przemawiają i poruszają się „patetycznie, wznosząc ręce do góry” [Gombrowicz 1997: 299]), ich ubiór stanowi część maski (niezliczone są w Operetce nazwy części garderoby: „pieniuah z kohonkami, obszyty futehkiem z wczesnego lisa jesiennego, shebrzystego, albo dezabil z suhowego jedwabiu z falbanką szkocką ...” [Gombrowicz 1997: 287], „pończoszki z mgiełki paryskiej” [Gombrowicz 2015: 286], „obfita koafiura, boa, rękawiczki, kolia, parasolka, kapelusz w ręku, mufka" [Gombrowicz 1997: 304]), wreszcie również sposób wysławienia poszczególnych postaci jest zmanierowany, wyraźnie stylizowany, wskazuje na ich przynależność społeczną, nieraz ogranicza się do wyrazów onomatopeicznych (np.: „MARKIZA Piti, piti” [Gombrowicz 1997: 275]), a w niektórych ustępach staje się niezrozumiałym bełkotem. Uderza sztuczny, emfatyczny sposób ukształtowania wypowiedzi. Postaci z wyższych sfer głoskę „,r” wymawiają jako „h”, dzięki czemu ich kwestie zyskują arystokratyczne zabarwienie. W ich wypowiedzi często wplątane są wyrazy pochodzenia francuskiego (lub niby-francuskiego) bądź nazwy wyszukanych dań, trunków, gier:

\section{SZARM}

Ten ghoteskowy baron! Daj mi cukiehka na oddech.

8 Poczucie przesycenia wielokrotnie powraca w utworze. Postaci nieraz ziewają ze znudzenia przewidywalnością realiów, w których funkcjonują, a które sterowane są dobrze znanymi im konwenansami. Przywołać warto też w tym kontekście postać Profesora cierpiącego na „chroniczny wymiot” (fizjologiczna reakcja na przesyt). 
Mam zgagę. Wczohajsze osthygi, szampan, pularda,

ha, ha, Leoncja, cette enchantehesse, mimosy i ohchidee, biżuterie i kakadu, tylko że potem dewena, parole d'honneur, ten bakahat w klubie $[\ldots]$.

[Gombrowicz 1997: 265]

Inny przykład:

SZARM

(śpiewa)

Och, co mi bahon!

ha, ha, ha, bahon!

Jam hhabia Szahm

Zdobywca dam!

Jam bihbant Szahm

I lampaht Szahm

Enfant gâté salonów, heu, heu, wąsik, monokl,

laseczka ma, szapoklak mój, maniehy me (ziewa)

A dogahessy

I phincessy

Kontessy, mieszczki, szwaczki i Murzynki

Och, och, dhogi, ach, nieodpahty, ach, sznytowy, ach, czahujący, ah quel chic, quel chahme et quelles manièhes!

[Gombrowicz 1997: 266]

Podobnie język lokajów jest ukształtowany w sposób mający charakteryzować ich przynależność do niższej warstwy społecznej i dopełniać ich „lokajskie gęby”:

\section{LOKAJ}

Cie, odstaw sie, gdzie sie pchasz?

II LOKAJ

To moja noga!

III LOKAJ

Tera takie noski od bucików som śpiczaste... 
ORDYNANS

Won, hołota, nie widzisz, że pana generała pucuję?

III LOKAJ

Tera szkapertki z prążkiem.

WŁADYSŁAW

Nie pchaj sie, bucu!

\section{KSIĘŻA GOSPODYNI}

Skaranie boże z tom hołotom!

\section{LOKAJ}

Zabrakło mnie pucu. Językiem wyliżę.

\section{LOKAJ}

Ja tyż glancu ni mom, ale mom ozor.

\section{GOSPODYNI}

Skaranie boże z temy chamamy.

\section{LOKAJ}

Walek, tu wyliż, spod obcasa.

LOKAJE (liżac)

Oj, pucem go do glancu!

I glancem go do pucu!

Ozorem!

\section{Ozorem!}

Hej ja, hej ha!

[Gombrowicz 1997: 277]

O ile w Operetce główną cechą postaci jest ich „gęba” społeczna, o tyle w komedii dell'arte jest nią reprezentatywność regionalna, a dopiero niejako $\mathrm{w}$ drugiej kolejności społeczna. Poszczególne postaci nie tylko są nosicielami stereotypowych cech przypisywanych mieszkańcom różnych regionów Włoch, 
lecz także manifestują swoją przynależność do konkretnej grupy społecznej, którą oddają, podobnie jak w Operetce, noszone przez nie maski, kostiumy oraz sposób mówienia. Przypomnijmy, że bohaterowie komedii dell'arte mówią w dialektach, co dopełnia ich charakterystyki jako postaci-szablonów, np. starzec z wyższej grupy społecznej mówi w dialekcie bolońskim (il Dottore), jego wypowiedzi stanowią parodię erudycyjnych wywodów'; z kolei służący (gli Zanni) często posługują się dialektem bergamasco, odbieranym jako ordynarny i dowcipny [Miklaszewski 1981: 48]; pokojówka (la Servetta), sprytna, zuchwała, dosadna w sposobie wysłowienia, która zwraca się do państwa z dużą swobodą i arogancją [Miklaszewski 1981: 41], zwykle mówi w dialekcie toskańskim, rzadziej mediolańskim i neapolitańskim [Miklaszewski 1981: 54]; język żołnierza-samochwała (il Capitano) cechuje hiperboliczność i patetyczny ton, opowiada o swoich wielkich przygodach i wyczynach w stylu barona Munchausena [Miklaszewski 1981: 57]. Warto odnotować, że choć niektóre stałe postaci włoskiej komedii dell'arte nie noszą masek - para Zakochanych (gli Innamorati) - to konwencja narzuca im konkretną „gębę”. Styl tych ról polega na ostentacyjnej deklamacji, sztucznych pozach, wypowiedziach inspirowanych tradycją literacką. Nadinterpretacją byłoby chyba dopatrywanie się głębszych analogii między postaciami Operetki a maskami z komedii dell'arte. Wymiotujący wciąż Profesor jako karykatura il Dottore? Lokaje i Gosposie odpowiednio jako gli Zanni i sprytne służki? Szarm i Albertynka jako gli Innamorati? Podobieństwa między postaciami nie są aż tak głębokie i realizują się raczej na poziomie ich konstrukcji jako typowych dla określonej rzeczywistości społecznej. Chodzi nie tyle o pokrewieństwo między konkretnymi postaciami, ile o ich porównywalność strukturalną jako postaci-szablonów.

W Operetce maski nie są stałe, lecz w pewnym sensie dynamiczne. Wraz z rozwojem wydarzeń ewoluują, przepoczwarzają się jedna w drugą. W pierwszym akcie oczom widza ukazują się postaci-marionetki, których drobiazgowo dopracowane stroje

9 Wyśmiewano ongiś mieszkańców Bolonii, którzy przekonani byli o swojej wyższości intelektualnej [por. Miklaszewski 1981: 41]. 
i wyreżyserowane ruchy dopełniają ich charakterystyki jako typowych przedstawicieli różnych grup społecznych. Są to maski-kostiumy społeczne:

KSIĄŻĘ

[...] sthój stał się najsilniejszym bastionem klasy wyższej.

Cóż by się działo, gdyby nie te wszystkie niuanse, rzekłbym, subtelności, odcienie, ten szyfh mistyczny, niezhozumiały dla niewtajemniczonych, któhym wyższa sfeha izoluje się od sfehy niższej. Sthój i maniehy, oto bastion nasz na wysokościach! Hosanna! Klasa niższa, rzecz phosta, hobi co może żeby przyswoić sobie zahówno naszą modę, jak nasze maniehy, ale też dlatego ciągle trzeba wphowadzać innowacje, mylące thop. [Gombrowicz 1997: 273]

W drugim akcie, podczas balu maskowego, postaci przywdziewają maski sensu stricto, które zasłaniają ich twarze, a resztę ciała chowają pod workami:

HUFNAGIEL

$[\ldots]$

Niech bal z okazji rewii mód

balem maskowym stanie się

Zamaskowany będzie bal!

Jak nasze, właśnie, czasy!

[...]

Maskowy bal, tajemny bal

W szeregu, ach, błyszczących sal

I najdziwniejszych pełen szat

Ze wszystkich epok, wszystkich lat!

$[\ldots]$

\section{HUFNAGIEL}

Jednakże wśród tych stroju fal

Niektórzy goście w workach będą

To workowatych będzie lud!

Worek na opak narzucony 
I w worku dziura, $\mathrm{z}$ dziury głowa

Wychodzi, lecz zamaskowana,

Że nie wiadomo, kto to jest!

[Gombrowicz 1997: 296-297]

Pod koniec II aktu w oniryczno-groteskowym tańcu i wirze rewolucji maski zostają zerwane, worki rozszarpane, ale spomiędzy ich strzępów wyzierają nowe maski, które prefigurują przyszłe dramatyczne wydarzenia (rewolucja, I i II wojna światowa): Książę i Księżna „w poszarpanych strojach” [Gombrowicz 1997: 335], Hufnagiel „,bez maski i worka: twarz okrwawiona, okropna, nienawistna” [Gombrowicz 1997: 335], Generałowi „zdarto do połowy maskę i nadszarpnięto worek. Generał jest w mundurze oficera hitlerowskiego, z monoklem, z rewolwerem..." [Gombrowicz 1997: 335], Markiza ,już bez maski i worka; Markiza jest ucharakteryzowana na dozorczynię w niemieckim obozie koncentracyjnym, z biczem, kajdanami etc." [Gombrowicz 1997: 335], Prezes „jest bez maski: ale na twarzy ma inną maskę, przeciwgazową, z olbrzymim ryjem; w ręku bomba" [Gombrowicz 1997: 335].

Wreszcie w III akcie ukazuje się kolejna odsłona maski: opadły maski społeczne, maski balowe i worki, opadły maski-przepowiednie ujawniające przyszłe dramatyczne wydarzenia, ale wyrastają nowe maski, dyktujące człowiekowi formę. W finale dramatu, w całkowitym zaburzeniu wszelkich porządków i logiki, niektóre maski mają charakter deantropomorfizacyjny - narzucają postaci formę zwierzęcia („Profesor na czworakach, osiodłany, z uzdą w ustach, podskakuje, chrapie" [Gombrowicz 1997: 342]), inne - deanimizacyjny, np. Książe-Lampa („Książę z wielkim abażurem na głowie, zasłaniającym twarz, udaje lampę" [Gombrowicz 1997: 338]) czy Księżna-Stolik (Fior „odskakuje od stolika, który jest Księżną na czworakach, przykrytą makatą" [Gombrowicz 1997: 338]), jeszcze inne zmieniają płeć: Proboszcz-Kobieta („Proboszcz wyłania się ze stosu rupieci. Sutanna spięta szpilkami w ten sposób, że wygląda na bluzkę i spódnicę. Na głowie duży kapelusz damski, w ręku parasolka" [Gombrowicz 1997: 340]). W momentach przepoczwarzania demonstrują się napięcia między „ja" wewnętrznym a maskami zewnętrznymi. W tym nieustającym 
przeobrażaniu się masek wewnętrzne „ja” postaci nigdy się nie emancypuje.

„Wszyscy się ukrywają i nie wie się, kim się jest...” [Gombrowicz 1997: 261]. W III akcie, gdy groteska i absurd osiągają apogeum, jedna z postaci, dyktator mody Fior, wyraża swoje zagubienie $\mathrm{w}$ świecie $\mathrm{w}$ takim stopniu zniekształconym przez przepoczwarzające się maski, że niemożliwa staje się racjonalna interpretacja rzeczywistości:

\section{FIOR}

Przepraszam, przepraszam, niewiele rozumiem, nie wyznaję się dobrze w mętach-odmętach tych dziwnych, dziwnych przeinaczeń, przebrań, przekształceń dzisiejszej mody, mody, mody... Mody na świata bezdrożach ... Męcząca maskarado! [Gombrowicz 1997: 355]

Nieustanna sukcesja masek ma reperkusje na poziomie samoświadomości postaci. Oto okazuje się, że przeobrażeniom i pęknięciom masek towarzyszy rozdarcie w obrębie jaźni postaci. Maska wyznaczała ramy ich tożsamości, ramy ich jestestwa. W warstwie językowej ilustruje to m.in. przejście od form czasu teraźniejszego czasownika „być” do form czasu przeszłego. W finalnych scenach dramatu „jestem” staje się „byłem”. Formy czasu teraźniejszego „jestem” oddają moment zrośnięcia postaci z maską, moment, w którym maska „wgryzła się” i „wżarła się" ${ }^{10}$ w postać: „Jam hhabia Szahm!” [Gombrowicz 1997: 266], „Jam baron jest Firulet” [Gombrowicz 1997: 267], „Bo jam jest Fior” [Gombrowicz 1997: 272], "Jam Albertynka” [Gombrowicz 1997: 272]. Z kolei formy czasu przeszłego „byłem” wyrażają zdystansowanie się postaci wobec maski:

\section{SZARM (do Firuleta)}

Spójrz no, czy to nie ten, co to tam kiedyś Fiohem był?... przeklinam i bluzek / zanadto w nas się wgryzł!” [Gombrowicz 1997: 357]. 
FIRULET

Coś jakby...

SZARM

Jeśli ja hesztki Fioha widzę, to Fioh widzi

Hesztki pewnego hhabiego, bahona...

FIOR

Ja Fiorem byłem...

SZARM

Ja Szahmem byłem...

FIRULET

Ja Firuletem ... ongiś...

KSIĄŻĘ-LAMPA

Mnie księciem ongiś zwano....

KSIĘŻNA-STOLIK

A mnie księżną...

HUFNAGIEL-JEŹDZIEC

Niegdyś lokajem ja byłem, a potem

Hufnaglem hrabią i jeźdźcem ....

PROBOSZCZ-KOBIETA

A ze mnie proboszcz był...

GENERAE

ze mnie generał...

PREZES

A ze mnie prezes

MARKIZA

A ze mnie markiza 


\section{wsZYscy (prócz lokai)}

Byliśmy, byliśmy, byliśmy, ex, ex, było

[Gombrowicz 1997: 351-352]

Być może to zdystansowanie jest tylko chwilowe: będzie trwało, póki kolejna maska nie „weżre się” w postać. Niestałość masek, skutkująca zdystansowaniem się postaci wobec własnej „gęby”, stanowi rozszerzenie paradygmatu maski komedii dell'arte, w której wprawdzie zdarzały się rozmaite przebieranki, postać podszywała się pod inną postać, niemniej maska miała charakter statyczny: każda maska oznaczała określony zestaw cech, które nie podlegały metamorfozom $^{11}$. Niezmienność atrybutów postaci-masek jest jedną z cech dystynktywnych komedii dell'arte. Jej zaburzenie można zaliczyć do narzędzi, które czynią z Operetki rodzaj dyskursu przeciw formie.

W odautorskim Komentarzu poprzedzającym właściwy tekst dramatu Gombrowicz [1997: 257] pisze, że „tekst sztuki nowoczesnej coraz mniej nadaje się do czytania. Coraz bardziej staje się partyturą, która żyć zaczyna dopiero na scenie, w grze, w spektaklu”. W ujęciu pisarza sztuka teatralna do momentu jej wystawienia na scenie stanowi więc jedynie surowy szkielet, zapis głosów i wskazówek, a osiąga swoją pełną realizację i ożywa dopiero w momencie jej wystawienia na scenie, w interakcji, jaka zachodzi między postaciami. W rozważaniach poświęconych teatralnej twórczości Gombrowicza Jerzy Jarzębski [2007: 93] odnotowuje, że „bohaterowie Gombrowicza zachowują się tak a nie inaczej bądź spontanicznie,

Por. „La caratteristica più peculiare e permanente della Commedia italiana, il suo aspetto più noto è costituito dai personaggi nettamente definiti e quasi immutabili, che si riducono a un esiguo numero di tipi teatrali popolari (tipi fissi). L'improvvisazione esigeva dall'attore una sicurezza assoluta in scena; egli doveva entrare nella parte e attenervisi rigorosamente. Ne conseguiva una rigida osservanza del ruolo al punto che il nome del personaggio serviva all'attore che lo recitava quale pseudonimo scenico. [...] Sono noti circa un centinaio di tipi comici italiani [...]. Ecco i personaggi principali dei comici italiani: i due vecchi (Pantalone e il Dottore), il primo e il secondo Zanni (servi comici, per esempio Brighella e Arlecchino), il Capitano, il primo e il secondo Innamorato, la prima e la seconda Donna innamorata, la Fantesca. Per gli scenari del primo periodo questi dieci tipi erano più che sufficienti e le compagnie, all'inizio, si componevano di 10-15 membri. Più tardi, nel periodo della decadenza, il numero degli attori andò sensibilmente aumentando" [Miklaszewski 1981: 38-39]. 
bądź pod naciskiem partnerów, jacy im towarzyszą”. Również dla komedii dell'arte znamienna jest improwizacja (stąd jedna z jej nazw: commedia all'improvviso, czyli „komedia improwizowana”) oraz to, że aktorzy stają się w pewnym stopniu autorami odgrywanych przez siebie postaci. Sposób realizacji poszczególnych ról na scenie zależy niemal wyłącznie od pomysłowości aktorów [Miklaszewski 1981: 9], którzy dysponują tylko zarysem akcji przedstawienia, tj. spisem scen (stąd nazwa: commedia a soggetto, czyli „komedia ze scenariuszem”), dzięki czemu dialogi rodzą się niejako spontanicznie na scenie. Na ich kształt mają też niemały wplyw gust i oczekiwania widzów.

Zatem zarówno u Gombrowicza, jak w komedii dell’arte niewątpliwie istotna jest kategoria improwizacji. U Gombrowicza improwizacja wydaje się niedoścignionym celem, ideałem, do którego pisarz dąży, doskonałą formą sztuki i życia. Jest momentem, w którym narzucona człowiekowi maska na chwilę się przekrzywia, ukazując coś autentycznego. Jednak w trakcie improwizacji partnerzy dialogu usiłują narzucić sobie nawzajem z powrotem maski. Symbolicznie realizuje się to w scenach, w których Albertynka pragnie nagości, a Szarm usiłuje ją ubrać:

\section{ALBERTYNKA}

Hrabio! Ty mnie ubierasz

Zamiast rozbierać!

SZARM

Pahdon? Pahdon? Pahdon?

\section{ALBERTYNKA}

Nie widzisz?

Ja pod sukienką moją

Jestem naga!

\section{SZARM}

Pieniuah z kohonkami, obszyty futehkiem z wczesnego lisa jesiennego, shebrzystego, albo dezabil z suhowego jedwabiu z falbanką szkocką... 


\section{ALBERTYNKA}

Nagość... Nagości chcę!

$[\ldots]$

\section{SZARM}

Piehwszy has widzę, żeby kobieta wolała hozbiehanie od ubiehania ...

[Gombrowicz 1997: 287-288]

Moment improwizacji okazuje się walką z formą. Jest to jednak walka skazana na porażkę. Ewokacja konwencji komedii dell'arte służy w utworze oddaniu teatralności ludzkiego istnienia, tego, że człowiek skazany jest na wieczne odgrywanie ról. Czy więc, pozostając w optyce Gombrowicza, prawdziwa improwizacja jest możliwa? Czy spontaniczne zachowanie jest możliwe? Człowiek jako wieczny aktor, narzuca ludziom, których spotyka, pewne wypracowane przez tradycje i konwencje scenariusze zachowań: „[...] nie ma ucieczki przed gębą, jak tylko w inną gębę” [Gombrowicz 1992: 264]. Człowiek nie istnieje bez maski:

[...] człowiek, chcąc nie chcąc, grzęźnie wciąż w gotowych językach i konwenansach, które nie tylko mu świat objaśniają, ale i jemu samemu wyznaczają w nim gotową rolę do odegrania. I tak - próbując się z tego więzienia form uwolnić - nieustannie popada w nowe uzależnienie, bo przecież bez formy w ogóle żyć nie może. Odbywa się to na wielu różnych poziomach: od poziomu zwyczajnych gestów do poziomu refleksji filozoficznej nad światem. [Jarzębski 2004: 60]

W Operetce popadanie z jednej formy w drugą ilustrują sceny, w których postaciom zostają zerwane maski, ale pod nimi są już następne, narzucające tym, którzy je noszą, sposób istnienia. Człowiek w ujęciu Gombrowicza jest więc niejako wiecznym więźniem swoistej komedii dell'arte. Jego przewaga nad postaciami-maskami z komedii dell'arte sensu stricto polega na tym, że może te maski zmieniać, choć nie ma na tym polu wolnej woli, zmiana maski odbywa się bowiem pod wplywem innych zamaskowanych postaci, 
realizujących wytyczone formy: „[... ] nie jesteśmy samoistni, jesteśmy tylko funkcją innych ludzi, musimy być takimi, jakimi nas widzą" [Gombrowicz 1992: 12]. Taki jest los Gombrowiczowskich postaci.

Wydawać by się mogło, że w komedii dell'arte postaci mają więcej swobody niż postaci Gombrowiczowskie, którym nieustannie inne postaci bądź sytuacje społeczne narzucają „gębę". Czy jest tak faktycznie? Skoro scenariusz komedii dell'arte nie uwzględnia szczegółowego zapisu dialogów i monologów postaci, aktorzy odgrywający poszczególne role mają sporą swobodę w zakresie autokreacji i samostanowienia. Improwizacja w komedii dell'arte, jeśli rozpatrujemy ją w optyce Gombrowiczowskiej, okazuje się jednak improwizacją pozorną, albowiem swoboda aktorów ograniczona jest nałożoną im maską i kostiumem oraz zachowaniem i wypowiedziami innych postaci-masek, o równie sztywnych wytycznych. Improwizowane dialogi postaci-masek są w istocie bardzo konwencjonalne i stanowią wyraźny przykład Gombrowiczowskiej koncepcji „gęby”. Maska reżyseruje niejako dialogi i sposób zachowania postaci, które wiedzą nie tylko, jak mają się zachowywać i wysławiać, lecz także jakich zachowań i wypowiedzi spodziewać się po swoich interlokutorach przyodzianych w konkretne maski-gęby. Aktorzy znają konwencję, której są niewolnikami, również improwizacja pełni niejako funkcję konwencji. W tym sensie postaci Operetki i aktorzy odgrywający poszczególne postaci-maski w komedii dell'arte są analogiczni w swym zniewoleniu formą.

Operetka to intertekstualny, eklektyczny, autotematyczny i chaotyczny dialog z formami i konwencjami, nie tylko literackimi i dramatycznymi, lecz także kulturowymi i społecznymi ${ }^{12}$. Chyba żaden

Ciekawą perspektywę wyznaczają w tym zakresie dwie płaszczyzny: metatekstualna i paratekstualna („paratekst autorski” [zob. Genette 1992: 317-366]). Do elementów metatekstualnych należałoby zaliczyć wszystkie zabiegi stylizacyjne stanowiące o dialogu z innymi konwencjami artystycznymi, natomiast na paratekst składają się, poprzedzające początek utworu, odautorski komentarz oraz streszczenie utworu, uwzględniające uwagi interpretacyjne i inscenizacyjne. Relacje z gatunkiem operetki i komedią dell’arte wytyczają płaszczyznę metatekstualną. Co ciekawe, płaszczyzna paratekstualna stanowi w utworze kolejną 
z elementów utworu nie istnieje w izolacji, ale wyłącznie w kontekście innego elementu, bądź występującego w obrębie samego utworu, bądź wobec niego zewnętrznego. Stylizacja w utworze realizuje się na różnych poziomach: od stylizacji języka bohaterów (tak aby charakteryzował on ich przynależność społeczną) przez naśladowcze odwołania do konwencji literackich i teatralnych po odwzorowywanie konwenansów społecznych. Można powiedzieć, że wszystkie te zabiegi stylizacyjne polegają na nakładaniu masek. W dramacie Gombrowicza jest ich wiele rodzajów (to istne panoptikum masek): od masek-gąb narzucanych sobie wzajemnie przez postaci i przez konwenanse, masek-kostiumów, w które przebierają się postaci, masek-konwencji literackich przez maskę komedii dell'arte po maskę operetkową, w którą Gombrowicz ubrał swój utwór, aby dokonać jego stylizacji na ten gatunek teatru. Operetka jawi się w tym świetle jako wielopoziomowa struktura maskowa. Poszczególne elementy konwencji, do których nawiązuje autor, wykorzystane zostają w sposób niezgodny z ich pierwotnym kontekstem funkcjonowania, stoją jakby w kontrze wobec samych siebie. Formy, do których odwołuje się Gombrowicz, są

tylko punktem odniesienia, swoistą skorupą, którą w końcu autor rozbija, propozycją pewnego języka, doprowadzanego przez pisarza do stanu krytycznego, kiedy poczyna on odsłaniać treści, których tradycyjna forma sztuki nie akceptuje bądź nie dostrzega. [Jarzębski 2007: 91]

Zasadniczym wątkiem Operetki jest, jak pisze sam Gombrowicz [1997: 263], „przeciwstawienie strój - nagość”, a utwór ma charakter snu „o nagości człowieka, uwięzionego w strojach najdziwaczniejszych i najokropniejszych" [Gombrowicz 1997: 263]. Mnogość masek ukazana jest przez „szaleństwo stroju” [Jarzębski 2007: 98]:

FIOR

Przeklinam ludzki strój, przeklinam maskę

„gębę", ponieważ modeluje oczekiwania odbiorcy, wyznaczając horyzont jego oczekiwań. 
Co nam się w ciało wżera, okrwawiona

Przeklinam mody, przeklinam kreacje

Krój pantalonów przeklinam i bluzek

zanadto w nas się wgryzł!

[Gombrowicz 1997: 357]

Zarówno w komedii dell'arte, jak i w Operetce maska i kostium determinują cechy postaci. W komedii dell'arte maska jest synonimem postaci, a w skrajnych przypadkach nawet aktora. W tym sensie maska staje się niejako „gębą” narzucaną aktorowi. Improwizacja, z której słynie komedia dell'arte, wymaga od aktora ogromnej pewności siebie na scenie i wejścia w rolę, jak najgłębszego zżycia się z maską. Nieuniknione było zrośnięcie się aktora z maską, którą posługiwał się nieraz przez całe życie na scenie. Zwykle imię odgrywanej postaci stawało się dożywotnim pseudonimem scenicznym aktora. Wiązało się to również z faktem, że nadzwyczaj rzadko aktor zmieniał rolę-maskę ${ }^{13}$. W Operetce okazuje się, że na maskę jest potencjalne antidotum. Jest nim nagość, dająca wyzwolenie od wszelkich „gąb”, wymuszających odgrywanie konkretnych ról. Nagość symbolizuje powrót do „wartości elementarnych i pierwotnej autentyczności, spontaniczności istnienia” [Jarzębski 1997: 8]. „Finałowa nagość Albertynki zdaje się być próbą odrzucenia gry i maski, swoistego «powrotu do raju»" [Jarzębski 2007: 98] konstatuje Jarzębski. W finale Albertynka jest naga i jedyne, co ją charakteryzuje, to nagość właśnie. O ile w Operetce można mówić o opozycji strój - nagość, o tyle w przypadku komedii dell'arte wydaje się to niemożliwe. W tym gatunku wyzwolenie od stroju-maski jest wykluczone, konwencja bowiem na to nie pozwala. Postaci komedii dell'arte nie istnieją bez kostiumu i maski. Maska i kostium to one. W Operetce pisarz nawiązuje do schematycznych, konwencjonalnych ujęć literackich i teatralnych rodem z komedii dell'arte, by zadać stałym, gotowym konwencjom „niewygodne pytanie” [Jarzębski 2007: 90-91]. To „niewygodne pytanie” ma

13 Na przykład Giovanni Pellesini grał służącego jeszcze w wieku osiemdziesięciu siedmiu lat, a Giovanni Andrea Zanotti rolę Zakochanego jako siedemdziesięciolatek [Miklaszewski 1981: 38]. 
skutkować nadpęknięciem zespolenia maski z człowiekiem. Gombrowicz traktuje gotowe formy teatralne instrumentalnie: służą one najpierw kreacji, a następnie demaskacji teatralności istnienia. W Operetce teatralność doprowadzona zostaje do stanu krytycznego [Jarzębski 2007: 98] poprzez aluzje do operetki i komedii dell'arte, czyli form teatralnych o szczególnym nasileniu teatralności.

\section{3. „Teatr doskonale teatralny” ${ }^{14}$ - kontekst komedii dell'arte w badaniach nad Operetka}

Przyjęta w artykule perspektywa badawcza polegała na spojrzeniu na Operetkę przez pryzmat konwencji komedii dell'arte. Niczym w pracowni fotograficznej nałożono na siebie dwa przeźrocza, by sprawdzić, w których miejscach kontury pokrywają się, a w których jakiś element wychodzi poza linię. W tym świetle Operetka jawi się jako uporczywe wychodzenie poza linię. I to nie tylko w zakresie wzorca komedii dell'arte, lecz także w zakresie wszystkich konwencji będących w utworze przedmiotem parodystycznego dialogu. Operetka jest zbudowana z wielu nakładających się na siebie przeźroczy, a kontury jednego obrazu wyzierają spod drugiego, zakłócając jego przejrzystość. To właśnie przez natrętne wychodzenie poza linie Operetka staje się dyskursem wbrew formie.

Powinowactwa z komedią dell'arte wyznaczają w dramacie Gombrowicza szczególny wymiar teatralności. Gatunek staje się w rękach pisarza narzędziem kontestacji, a teatralność stopniowo, przez pęknięcia masek-konwencji, doprowadzona zostaje do „ostatecznej destrukcji” [Jarzębski 2007: 95], „tkanina teatralności rozdziera się raptownie" [Jarzębski 2007: 98], świat przedstawiony staje się obcy, chaotyczny, paradoksalny. „Rozdarcie tkaniny teatralności” ma swoje reperkusje również dla postaci, które miotają się między maskami. Poprzez ewokację konturów maski komedii dell'arte i jednoczesne radykalne wyjście poza te kontury Operetka przeistacza się w studium „granicy, gdzie kończy się ja i nie-ja”, granicy, o której pisze Czesław Miłosz [1988: 8] w wierszu To jedno: „[...] / Być samym czystym patrzeniem bez nazwy, / Bez oczekiwań, lęków, nadziei, / Na granicy, gdzie kończy się ja i nie-ja”. 
Zarówno w komedii dell'arte, jak i w dramacie Gombrowicza postaciom przez nałożenie masek narzucone zostają „gęby”. Postaci nie mogą być sobą, mogą być tylko takie, jak maski, które zostały im przydzielone, stają się ich więźniami. „Czyste patrzenie bez nazwy / bez oczekiwań, lęków, nadziei” okazuje się więc chyba w obu przypadkach nieosiągalne.

\section{Bibliografia}

Apollonio Mario (1982), Storia della commedia dell'arte, Sansoni, Firenze. Błoński Jan (1994), Forma, śmiech i rzeczy ostateczne. Studia o Gombrowiczu, Znak, Kraków.

Chomicki Jerzy (2001), Operetka [hasło], w: Encyklopedia muzyki, red. Andrzej Chodakowski, Pwn, Warszawa, s. 635-636.

Fava Antonio (1999), La maschera comica nella commedia dell'arte, Andromedia Editrice, Colledara.

Genette Gérard (1992), Palimpsesty. Literatura drugiego stopnia, przeł. Aleksander Milecki, w: Wspótczesna teoria badań literackich za granica. Antologia, t. 4, cz. 2, red. Henryk Markiewicz, Wydawnictwo Literackie, Kraków, s. 317-366.

Głowiński Michał (2002), Gombrowicz i nadliteratura, Wydawnictwo Literackie, Kraków.

Gombrowicz Witold (1992), Ferdydurke, Wydawnictwo Literackie, Kraków.

Gombrowicz Witold (1997), Operetka, w: tegoż, Iwona, księżniczka Burgunda; Ślub; Operetka, Historia, Wydawnictwo Literackie, Kraków, s. 257-368.

Jarzębski Jerzy (1971), Pojęcie "formy” u Gombrowicza, „Pamiętnik Literacki", t. 62, z. 4, s. 69-96.

Jarzębski Jerzy (1997), Dramat Ego w dramacie historii [słowo wstępne], w: Witold Gombrowicz, Iwona, księżniczka Burgunda; Ślub; Operetka, Wydawnictwo Literackie, Kraków, s. 5-11.

Jarzębski Jerzy (2004), Gombrowicz, Wydawnictwo Dolnośląskie, Wrocław.

Jarzębski Jerzy (2007), Gombrowicz teatralny, w: tegoż, Natura i teatr. 16 tekstów o Gombrowiczu, Wydawnictwo Literackie, Kraków, s. 88-100.

Mariti Luciano, red. (1980), Alle origini del teatro moderno. La commedia dell'arte, Bulzoni, Roma.

Mazurkiewicz Filip (2016), Niewidzialna „Operetka” Witolda Gombrowicza. Od męskości hegemonicznej ku męskości atopicznej, „Pamiętnik Literacki”, t. 107, z. 2, s. 113-136. 
Miklaszewski Konstantin (1981), La commedia dell'arte o il teatro dei commedianti italiani nei secoli XVI, XVII e XVIII, z esejem autorstwa Carli Solivetti, Marsilio Editori, Venezia.

Miłosz Czesław (1988), To jedno, w: tegoż, Kroniki, Znak, Kraków, s. 8. Nicoll Allardyce (1967), W świecie Arlekina. Studium o komedii dell'arte, przeł. Antoni Dębnicki, PIw, Warszawa.

Nyczek Tadeusz (1996), „Operetka”, czyli w stroju i na goło. „Operetka” i operetka, w: O Witoldzie Gombrowiczu: materiały z sesji w 95 rocznicę urodzin i 3 rocznicę śmierci pisarza, red. Elżbieta Brodowska-Skonieczna, Wojewódzka Biblioteka Publiczna, Kielce, s. 49-70.

Pandolfi Vito (1957-1961), La commedia dell'arte. Storia e testo, t. 1-6, Sansoni, Firenze.

Surma-Gawłowska Monika (2015), Komedia dell’arte, Universitas, Kraków.

Taviani Ferdinando (1969), La commedia dell'arte. La fascinazione del teatro, Bulzoni, Roma.

Trojanowska Tamara (1989), Teatralne konsekwencje operetki w „Operetce”, „Dialog”, nr 5/6, s. 168-174.

Nadzieja Bąkowska

\section{Mask or Mug? Witold Gombrowicz's Operetka in the Context of Commedia Dell'arte}

The article is an attempt at placing Operetka (Operetta) in the context of commedia dell'arte by comparing the basic structural and ideological characteristics of Witold Gombrowicz's drama with the key traits of the commedia dell'arte genre. The author of Ferdydurke, who coined the phrase przyprawiać (komuś) gębę (put the screws to someone's mug), brings to the grotesque distortion any manifestations of form domination both in life and in art. Ironically, it is the elements of Operetka, related to commedia dell'arte - a thoroughly conventionalised and schematised genre, that become the tool for a sort of removal of mask or mug. Given the mask, protagonists are given "a mug", and cannot be themselves, they can only be what is allowed by the mask they were given and so they become its prisoner, in a way. The only antidote to "the mug" is nudity that frees one from any mask that forces them to play the designated roles.

The article aims to present the relationship between Operetka and the commedia dell'arte genre, with particular emphasis on analysing the Gombrowicz's concept of form against the convention of mask and costume in the commedia dell'arte, and on the "nudity" vs. "mask" opposition 
that focuses the drama's main artistic and existential issues, while it is also precisely the point where the relationship between Gombrowicz's work and Italian commedia dell'arte is seen most clearly.

Keywords: Gombrowicz; Operetka; Polish-Italian relations; commedia dell'arte; maska; gęba; mug; comparative studies.

Nadzieja Bąkowska - polonistka i komparatystka, aktualnie jako badacz postdoc realizuje projekt badawczy na temat autoprzekładu na Uniwersytecie Bolońskim. W 2020 roku obroniła rozprawę doktorską na Wydziale Neofilologii (Katedra Italianistyki) Uniwersytetu Warszawskiego, w ramach wspólnej opieki naukowej cotutelle z Uniwersytetem Bolońskim. Absolwentka studiów polonistycznych na Uniwersytecie Warszawskim i polonistyczno-komparatystycznych na Uniwersytecie Bolońskim. Jej zainteresowania naukowe obejmują polsko-włoską komparatystykę literacką, teorię i praktykę przekładu, autoprzekład, teorię literatury i teorię dramatu, zjawiska komizmu i metafikcji. Autorka artykułów naukowych o tej tematyce, a także przekładów literatury i tekstów naukowych z języka polskiego na włoski i vice versa. 
